\title{
Assembly of MiniFuel Targets for Irradiation of TRISO Fuel Compacts in the High Flux Isotope Reactor
}

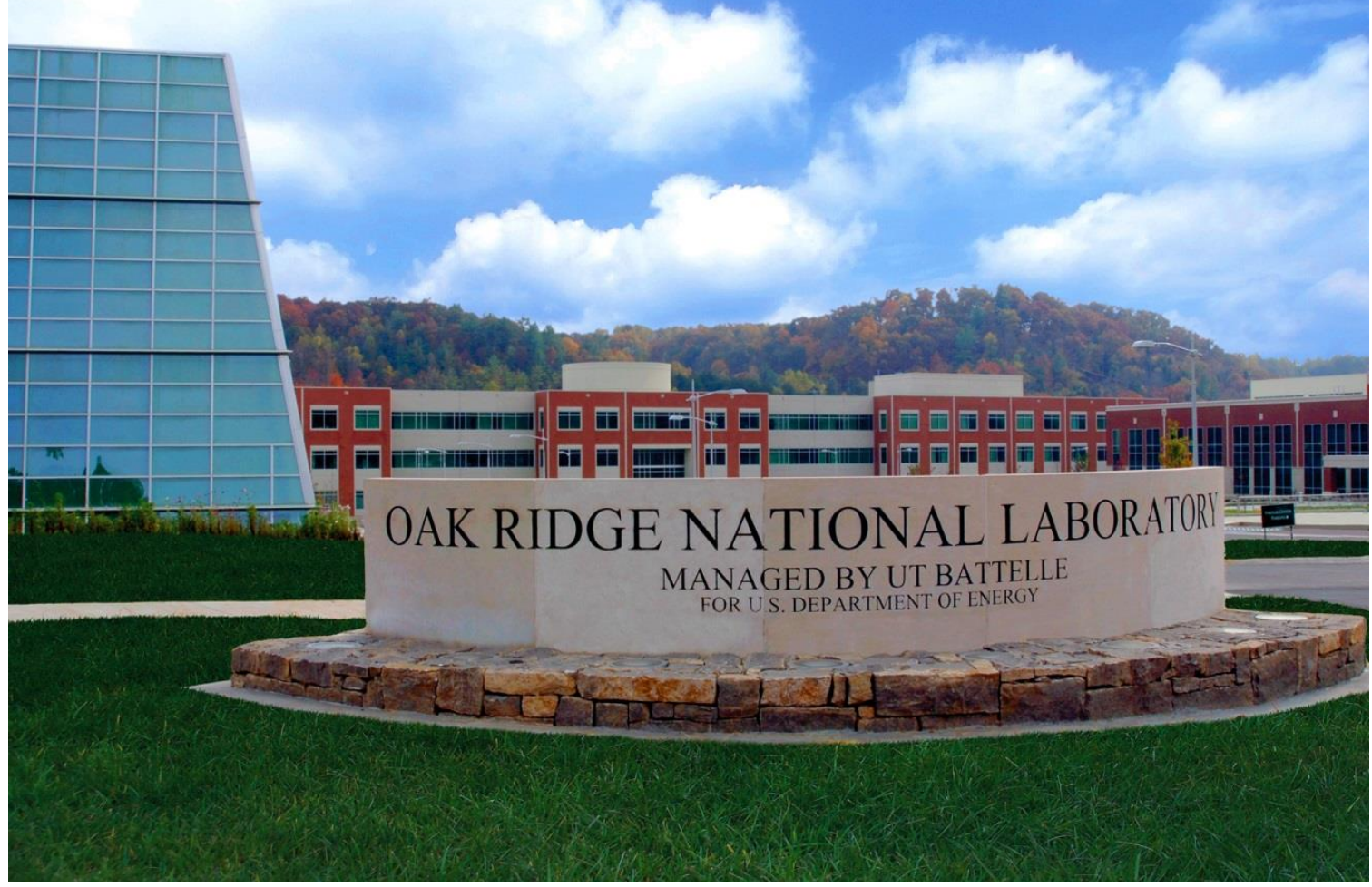
A.G. Le Coq
R.C. Gallagher
K.D. Linton
R. Latta (Kairos Power)
B. Collin (Kairos Power)

July 2021

M3UF-21OR0212013 


\title{
DOCUMENT AVAILABILITY
}

Reports produced after January 1, 1996, are generally available free via US Department of Energy (DOE) SciTech Connect.

Website www.osti.gov

Reports produced before January 1, 1996, may be purchased by members of the public from the following source:

\author{
National Technical Information Service \\ 5285 Port Royal Road \\ Springfield, VA 22161 \\ Telephone 703-605-6000 (1-800-553-6847) \\ TDD 703-487-4639 \\ Fax 703-605-6900 \\ E-mail info@ntis.gov \\ Website http://classic.ntis.gov/
}

Reports are available to DOE employees, DOE contractors, Energy Technology Data Exchange representatives, and International Nuclear Information System representatives from the following source:

Office of Scientific and Technical Information

PO Box 62

Oak Ridge, TN 37831

Telephone 865-576-8401

Fax 865-576-5728

E-mail reports@osti.gov

Website http://www.osti.gov/

This report was prepared as an account of work sponsored by an agency of the United States Government. Neither the United States Government nor any agency thereof, nor any of their employees, makes any warranty, express or implied, or assumes any legal liability or responsibility for the accuracy, completeness, or usefulness of any information, apparatus, product, or process disclosed, or represents that its use would not infringe privately owned rights. Reference herein to any specific commercial product, process, or service by trade name, trademark, manufacturer, or otherwise, does not necessarily constitute or imply its endorsement, recommendation, or favoring by the United States Government or any agency thereof. The views and opinions of authors expressed herein do not necessarily state or reflect those of the United States Government or any agency thereof. 
Nuclear Energy and Fuel Cycle Division

\title{
ASSEMBLY OF MINIFUEL TARGETS FOR IRRADIATION OF TRISO FUEL COMPACTS IN THE HIGH FLUX ISOTOPE REACTOR
}

\author{
A.G. Le Coq \\ R.G. Gallagher \\ K.D. Linton \\ R. Latta (Kairos Power) \\ B. Collin (Kairos Power)
}

July 2021

M3UF-21OR0212013

\author{
Prepared by \\ OAK RIDGE NATIONAL LABORATORY \\ Oak Ridge, TN 37831-6283 \\ managed by \\ UT-BATTELLE LLC \\ for the \\ US DEPARTMENT OF ENERGY \\ under contract DE-AC05-00OR22725
}





\section{CONTENTS}

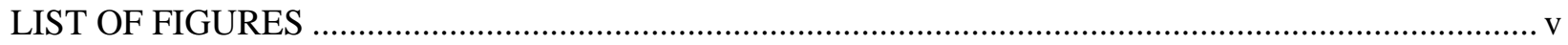

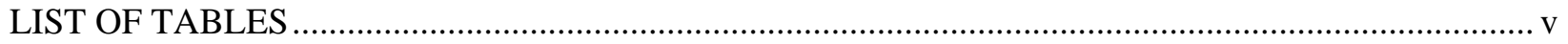

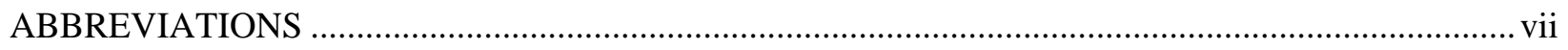

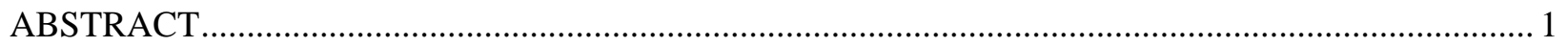

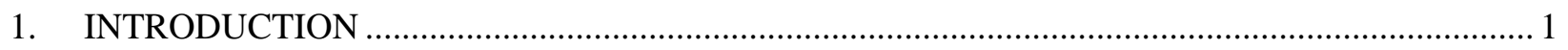

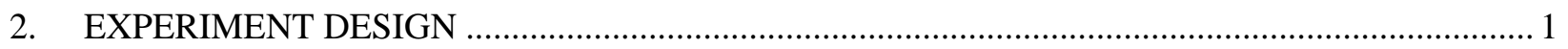

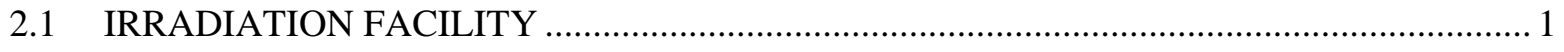

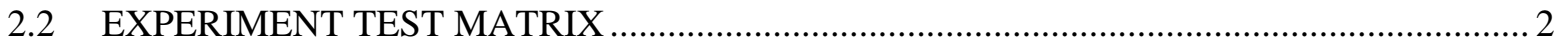

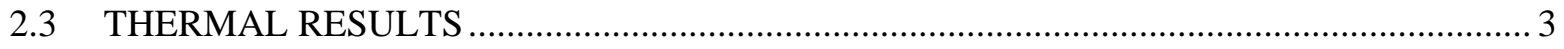

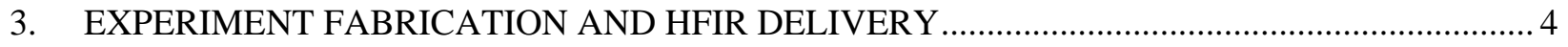

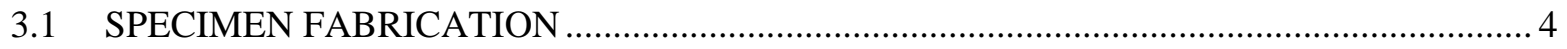

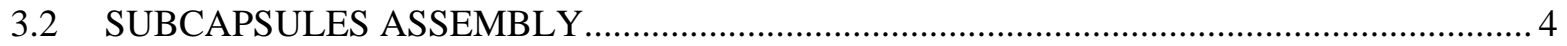

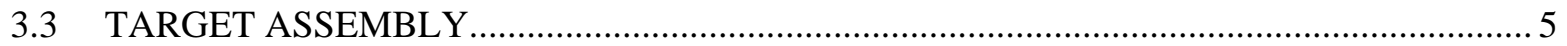

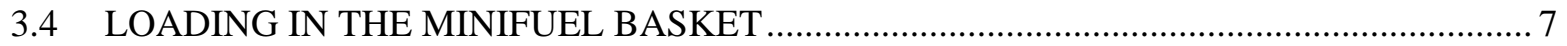

3.5 FABRICATION PACKAGE AND DELIVERY TO HFIR …...................................... 7

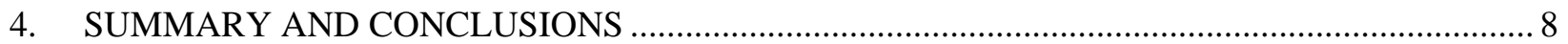

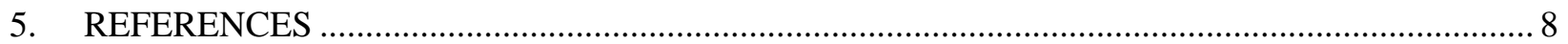

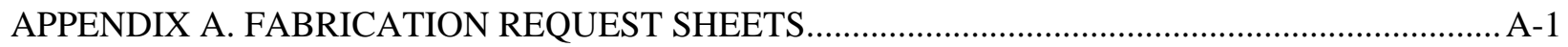

APPENDIX B. EXPERIMENT AUTHORIZATION BASES DOCUMENT ….................................. B-1 



\section{LIST OF FIGURES}

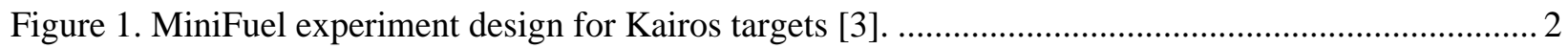

Figure 2. Subcapsule parts layout (Credit: ORNL, US Department of Energy)...................................... 4

Figure 3. Subcapsules after EB welding (Credit: ORNL, US Department of Energy)..............................5

Figure 4. Parts layout of one target assembly: individual parts layout (top) and assembly of centering thimbles and subcapsules (bottom) (Credit: ORNL, US Department of Energy)........... 6

Figure 5. Final target fully welded (top), and radiography of the welds (bottom left and right) (Credit: ORNL, US Department of Energy).

\section{LIST OF TABLES}

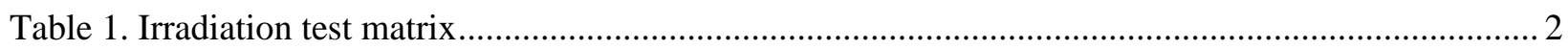

Table 2. Thermal results of TRISO SiC layer for each target................................................................ 3

Table 3. Characteristic of the fuel for each type of compact ................................................................. 4 



\section{ABBREVIATIONS}

AGR Advanced Gas Reactor

EABD experiment authorization bases document

EB electron beam

FHR fluoride-salt cooled high-temperature reactor

HFIR High Flux Isotope Reactor

KP Kairos Power

ORNL Oak Ridge National Laboratory

PIE post-irradiation examination

QA quality assurance

$\mathrm{SiC} \quad$ silicon carbide

TRISO tristructural isotropic

VXF vertical experiment facility 



\begin{abstract}
To support the development of Kairos Power's fluoride-salt-cooled high-temperature reactor, irradiation testing of tristructural isotropic (TRISO) fuel compacts was performed at the Oak Ridge National Laboratory (ORNL) High Flux Isotope Reactor (HFIR) to collect experimental data on TRISO fuel during high particle-power operation and validate fuel performance models. Fuel compacts containing enriched uranium oxycarbide (UCO), natural UCO (NUCO), or uranium dioxide $\left(\mathrm{UO}_{2}\right)$ TRISO particles were fabricated at ORNL and inserted into MiniFuel targets for HFIR irradiation. Five MiniFuel targets were successfully assembled, welded, tested, and delivered to HFIR, along with their quality assurance documentation. The targets were inserted into HFIR's inner vertical experiment facility within the permanent beryllium reflector. Each target contains six fuel compacts and will be irradiated in HFIR for four cycles, with target temperatures of 500,700 , and $900^{\circ} \mathrm{C}$. This report summarizes the experiment design, test matrix, and fabrication. This work was performed under the Nuclear Science User Facility program.
\end{abstract}

\title{
1. INTRODUCTION
}

The fluoride-salt-cooled high-temperature reactor (FHR) concept developed by Kairos Power (KP) leverages tristructural isotropic (TRISO) fuel in pebble form, combined with a low-pressure fluoride salt coolant. The heat transfer properties of molten salt enable high-power density, resulting in high particle powers relative to advanced gas-cooled reactor concepts. Part of the FHR development effort includes collection of experimental data on TRISO fuel during high particle power operation to validate fuel performance models and to predict the particle failure proportion. High-power TRISO particle irradiation testing is expected to demonstrate significant performance margin compared to that shown in current U.S. Advanced Gas Reactor (AGR) irradiation tests, which were performed at significantly higher temperatures $\left(\sim 800-1,300^{\circ} \mathrm{C}\right)$ compared to FHR temperatures $\left(500-700^{\circ} \mathrm{C}\right)$.

KP and Oak Ridge National Laboratory (ORNL) have developed an irradiation campaign to investigate TRISO particle fuel performance at temperatures similar to those in an FHR core. Different kernel compositions are being explored to presumably demonstrate improved fuel performance with uranium oxycarbide (UCO) kernels at very high powers; uranium dioxide $\left(\mathrm{UO}_{2}\right)$ particles serve as a test control and have historically been the standard for high performance particle fuels [1][2]. This report summarizes the experiment design, test matrix, and fabrication.

\section{EXPERIMENT DESIGN}

\subsection{IRRADIATION FACILITY}

The experiment design is detailed in the report by Gallagher et al. [3] and is summarized in this section. Figure 1 illustrates the components of the MiniFuel experiment design. The experiment facility consists of an aluminum basket with three radial positions $(\mathrm{R}=1,2,3)$ and three axial positions $(\mathrm{A}=1,2,3)$, for a total of 9 positions. Two of the radial positions face the core $(\mathrm{R}=2$ and 3$)$, and the middle axial position $(\mathrm{A}=2)$ is located around the core's mid-plane. MiniFuel targets can be inserted in each radial position and stacked at each axial position. A MiniFuel target is made of a stainless-steel tube sealed on both ends which contains a stack of six individually sealed subcapsules. The positions of the subcapsules in the target are referred to as $S=1$ (bottom position) through $S=6$ (top position). Centering thimbles made of titanium alloy are placed at each end of the subcapsules, ensuring that the gas gap between the target tube and the subcapsule is radially uniform and cannot be displaced during irradiation. The target irradiation temperature of the fuel specimens is controlled by the size of the gas gap and the fill gas thermal conductivity, which is a mixture of helium and argon gas. The subcapsule is composed of Mo and contains the fuel specimen, $\mathrm{SiC}$ 
spacers, a Mo insert tube, SiC passive thermometry, a graphite fission product sink, and grafoil disks. A Mo end cap is welded to the holder to seal the subcapsule. All subcapsules are sealed with pure helium backfill gas.

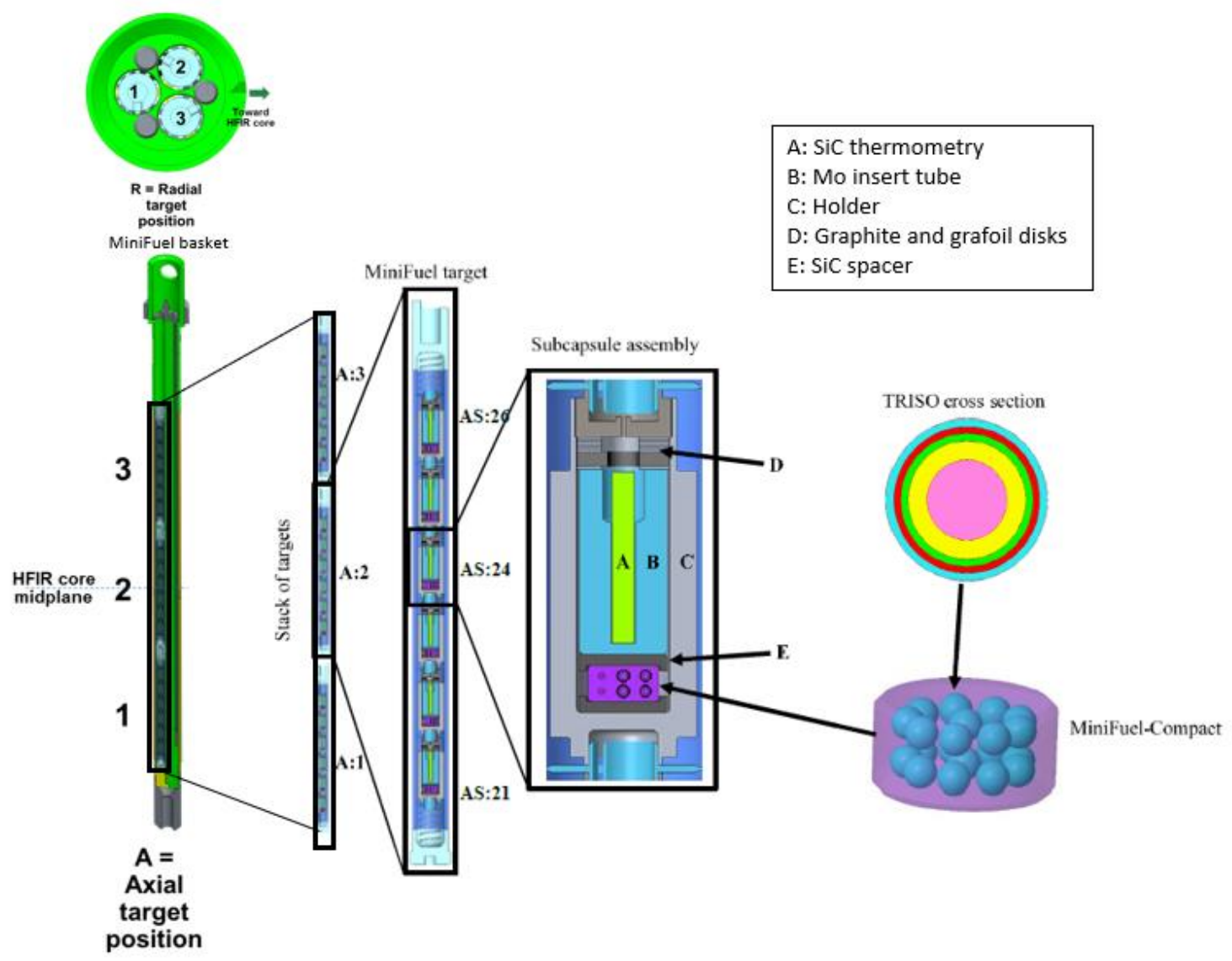

Figure 1. MiniFuel experiment design for Kairos targets [3][1].

\subsection{EXPERIMENT TEST MATRIX}

Table 1 provides details of the experiment irradiation test matrix, the irradiation conditions, and the specimens being inserted in the targets. Each target contains 6 TRISO compacts, containing UCO, natural $\mathrm{UCO}$ (NUCO), or $\mathrm{UO}_{2}$ kernels (see section 3.1). The irradiation locations specified in Table 1 correspond to the as-inserted in HFIR target location in the MiniFuel basket.

Table 1. Irradiation test matrix

\begin{tabular}{|c|c|c|c|c|c|}
\hline $\begin{array}{l}\text { Target } \\
\text { ID }\end{array}$ & $\begin{array}{c}\text { Number of } \\
\text { irradiation } \\
\text { cycles }\end{array}$ & $\begin{array}{c}\text { Target } \\
\text { temperature } \\
\left({ }^{\circ} \mathbf{C}\right)\end{array}$ & Compacts & $\begin{array}{c}\text { Irradiation } \\
\text { location }(\mathbf{R}-\mathbf{A})\end{array}$ & Target fill gas \\
\hline KP01 & \multirow{5}{*}{4} & 900 & $3 \mathrm{UCO}+3 \mathrm{UO}_{2}$ & $1-2$ & $\mathrm{Ar}$ \\
\hline KP02 & & 500 & $3 \mathrm{UCO}+3 \mathrm{NUCO}$ & $3-2$ & Ne equivalent (59.5\% Ar/ He bal.) \\
\hline KP03 & & 500 & $6 \mathrm{UCO}$ & $3-3$ & $\mathrm{Ne}$ equivalent $(59.5 \% \mathrm{Ar} / \mathrm{He}$ bal. $)$ \\
\hline KP04 & & 700 & $3 \mathrm{UCO}+3 \mathrm{NUCO}$ & $2-2$ & $\mathrm{Ne}$ equivalent (59.5\% Ar/ He bal.) \\
\hline KP05 & & 700 & $6 \mathrm{UCO}$ & $2-3$ & $78 \% \mathrm{Ar} / 22 \% \mathrm{He}$ \\
\hline
\end{tabular}




\subsection{THERMAL RESULTS}

To predict the irradiation temperatures of the MiniFuel compacts, neutronic and thermal analyses were performed [3]. The target temperature for each compact was defined by the time-averaged and volumeaveraged irradiation temperature of the specimen TRISO SiC layers. Table 2 summarizes the thermal results [3] for each target. The radial irradiation location of the targets in the MiniFuel basket considered in the neutronic and thermal analyses [3] is different from the actual radial location where the targets were loaded for irradiation in HFIR: targets KP02/KP03 and KP04/KP05 were loaded in radial position $\mathrm{R}=3$ and $\mathrm{R}=2$, respectively, whereas they were considered in radial position $\mathrm{R}=2$ and $\mathrm{R}=3$, respectively, in the numerical analyses [3]. The as-irradiated target thermal analyses will be completed and reported in a future document.

Table 2. Thermal results of TRISO SiC layer for each target

\begin{tabular}{|c|c|c|c|c|c|c|c|c|}
\hline \multirow{2}{*}{ Target ID } & \multirow{2}{*}{\multicolumn{2}{|c|}{ Temperature $\left({ }^{\circ} \mathrm{C}\right)$}} & \multicolumn{6}{|c|}{ Subcapsule position } \\
\hline & & & $S=1$ & $\mathrm{~S}=2$ & $\mathrm{~S}=\mathbf{3}$ & $S=4$ & $S=5$ & $S=6$ \\
\hline \multirow{4}{*}{ KP01 } & \multirow{3}{*}{ TRISO SiC layers } & average & 885 & 892 & 888 & 888 & 884 & 884 \\
\hline & & maximum & 985 & 997 & 996 & 1001 & 990 & 985 \\
\hline & & minimum & 820 & 827 & 822 & 819 & 818 & 820 \\
\hline & SiC thermometry & average & 895 & 899 & 897 & 895 & 892 & 894 \\
\hline \multirow{4}{*}{ KP02 } & \multirow{3}{*}{ TRISO SiC layers } & average & 485 & 497 & 489 & 497 & 486 & 493 \\
\hline & & maximum & 561 & 516 & 569 & 516 & 565 & 511 \\
\hline & & minimum & 437 & 471 & 440 & 472 & 438 & 469 \\
\hline & SiC thermometry & average & 495 & 499 & 499 & 500 & 497 & 501 \\
\hline \multirow{4}{*}{ KP03 } & \multirow{3}{*}{ TRISO SiC layers } & average & 485 & 483 & 485 & 487 & 486 & 489 \\
\hline & & maximum & 551 & 550 & 552 & 554 & 552 & 553 \\
\hline & & minimum & 436 & 435 & 438 & 441 & 442 & 447 \\
\hline & SiC thermometry & average & 493 & 491 & 492 & 494 & 495 & 499 \\
\hline \multirow{4}{*}{ KP04 } & \multirow{3}{*}{ TRISO SiC layers } & average & 673 & 690 & 675 & 688 & 676 & 682 \\
\hline & & maximum & 764 & 718 & 766 & 715 & 765 & 707 \\
\hline & & minimum & 616 & 652 & 620 & 651 & 622 & 647 \\
\hline & SiC thermometry & average & 690 & 699 & 691 & 697 & 693 & 699 \\
\hline \multirow{4}{*}{ KP05 } & \multirow{3}{*}{ TRISO SiC layers } & average & 677 & 679 & 678 & 679 & 677 & 675 \\
\hline & & maximum & 757 & 760 & 760 & 761 & 759 & 755 \\
\hline & & minimum & 618 & 619 & 620 & 621 & 620 & 620 \\
\hline & SiC thermometry & average & 693 & 692 & 692 & 693 & 693 & 695 \\
\hline & $\begin{array}{r}\mathrm{UC} \\
\mathrm{NUC} \\
\mathrm{UC}\end{array}$ & & & & & & & \\
\hline
\end{tabular}




\section{EXPERIMENT FABRICATION AND HFIR DELIVERY}

\subsection{SPECIMEN FABRICATION}

ORNL fabricated fuel compacts for this experiment [4]. Each compact contains $20 \mathrm{UCO}, \mathrm{NUCO}$, or $\mathrm{UO}_{2}$ TRISO particles compacted in a carbon matrix. The TRISO particles were not fabricated as part of this work but were existing AGR-2 particles. Table 3 shows the uranium content per compact, enrichment, and mass of ${ }^{235} \mathrm{U}$.

Table 3. Characteristic of the fuel for each type of compact

\begin{tabular}{|c|c|c|c|c|}
\hline $\begin{array}{c}\text { Compact/ } \\
\text { kernel type }\end{array}$ & Batch \# & Enrichment & $\begin{array}{l}U \text { mass per } \\
\text { compact }(\mathrm{g})\end{array}$ & $\begin{array}{l}{ }^{235} \mathrm{U} \text { mass per } \\
\text { compact }(\mathrm{g})\end{array}$ \\
\hline NUCO & NUCO 425-08T & $0.71 \%$ & 0.00761 & 0.00005 \\
\hline $\mathrm{UCO}$ & LEU09 & $14.029 \%$ & 0.00762 & 0.00107 \\
\hline $\mathrm{UO}_{2}$ & LEU11 & $9.60 \%$ & 0.01215 & 0.00117 \\
\hline
\end{tabular}

Pre-characterization of the compacts included dimensional inspection, density measurements, and x-ray computed tomography to provide data on kernel volume and position in the compact. The precharacterization data are summarized in Gerczak et al. [5].

\subsection{SUBCAPSULES ASSEMBLY}

A total of 30 subcapsules were assembled. Figure 2 shows the parts layout for one subcapsule. The signed subassembly fabrication request forms are provided in Appendix A.

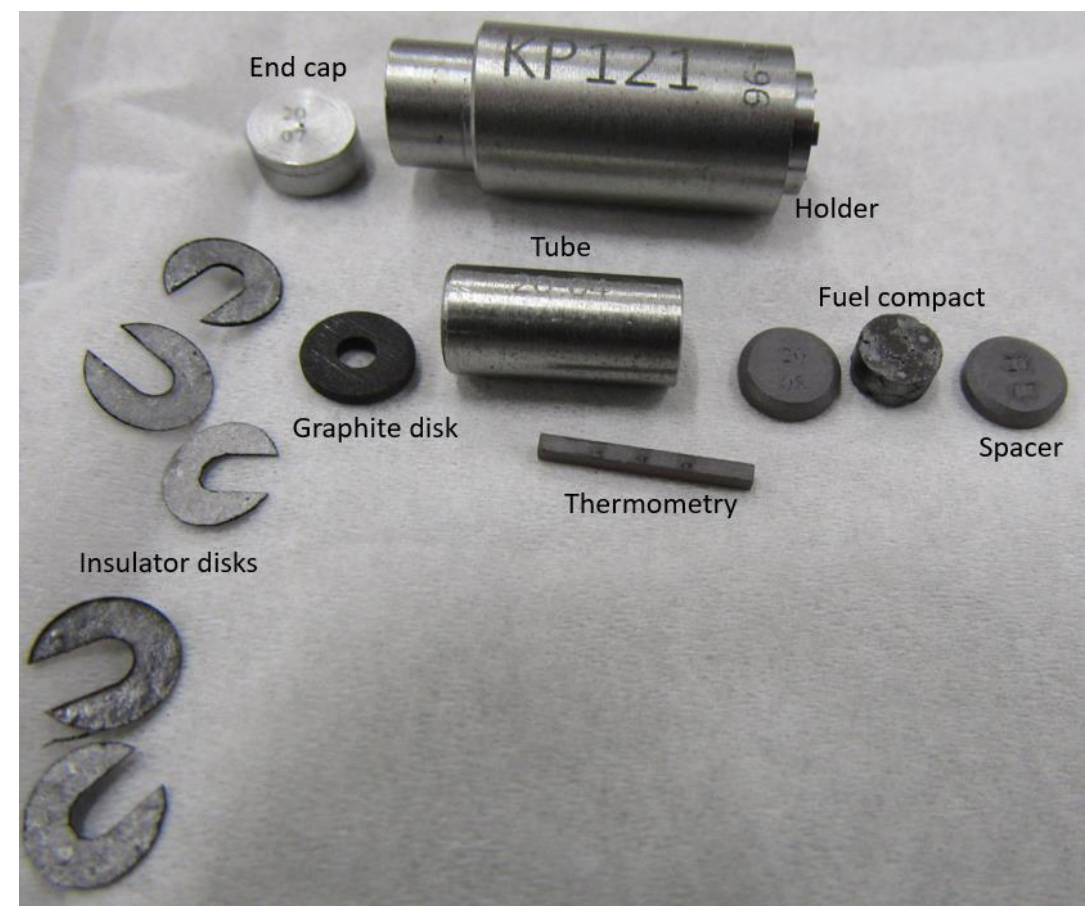

Figure 2. Subcapsule parts layout (Credit: ORNL, US Department of Energy). 
All subcapsule components were dimensionally inspected and cleaned according to HFIR-approved procedures, drawings, and sketches. After internal components were assembled, the subcapsule end caps were welded to the subcapsule bodies using an electron beam (EB) weld. Figure 3 shows the subcapsules after EB welding. The subcapsules assemblies were then placed inside sealed containers that were evacuated and backfilled with ultra-high purity helium three times to ensure a pure environment. The containers were placed inside a glovebox which was also evacuated and backfilled with the same gas that was used in the sealed containers, to a pressure equivalent to local atmospheric pressure. A small hole was seal-welded in each subcapsule end cap using a gas tungsten arc welding procedure. All welds passed visual examination. Each subcapsule was then sent for nondestructive examination, which included a bubble test and a helium leak test. All assemblies passed the nondestructive examination.

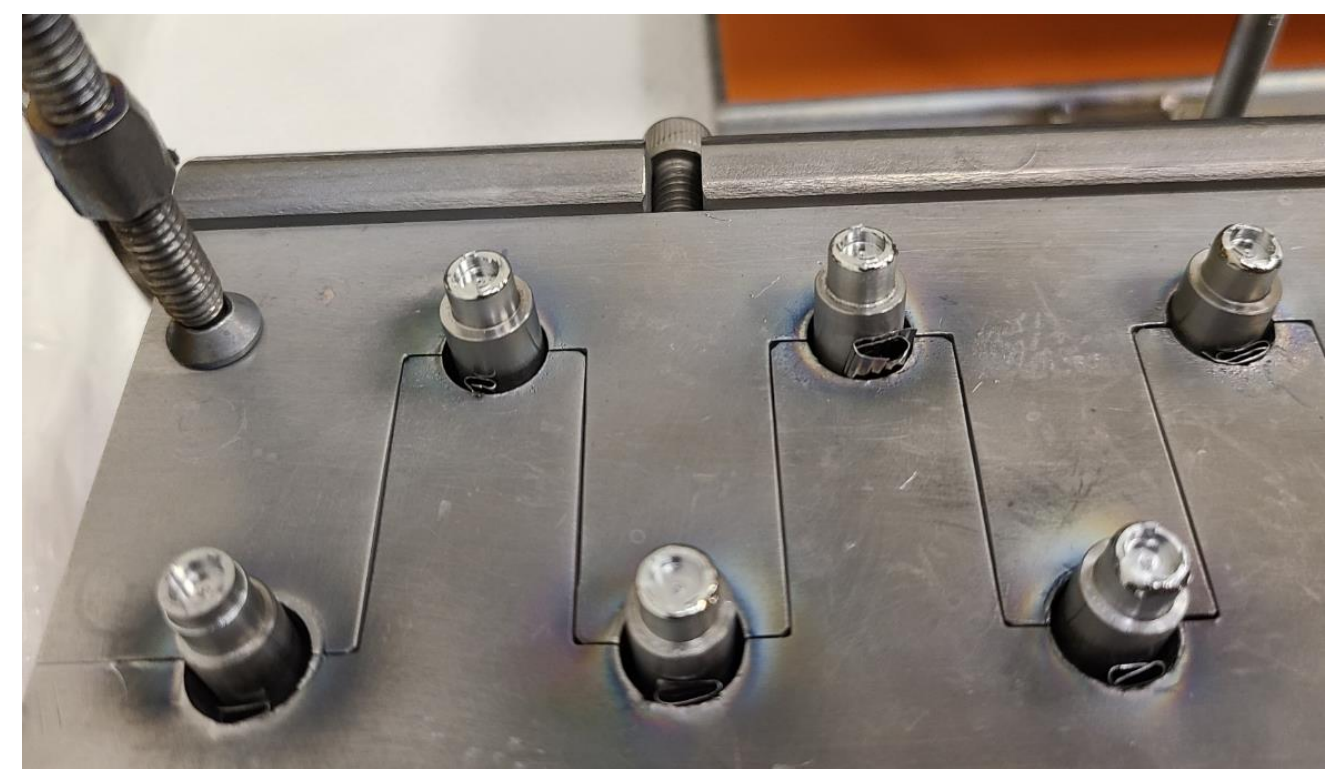

Figure 3. Subcapsules after EB welding (Credit: ORNL, US Department of Energy).

\subsection{TARGET ASSEMBLY}

Five targets were assembled, each containing 6 subcapsules. The parts layout for one target assembly is shown in Figure 4. As can be seen in this figure, the target bottom end cap was welded to the target housing before the subcapsules were loaded. The signed target fabrication request forms are provided in Appendix A. The irradiation locations specified on the fabrication request forms do not correspond to the actual locations where the targets were loaded for HFIR irradiation (see Table 1). 

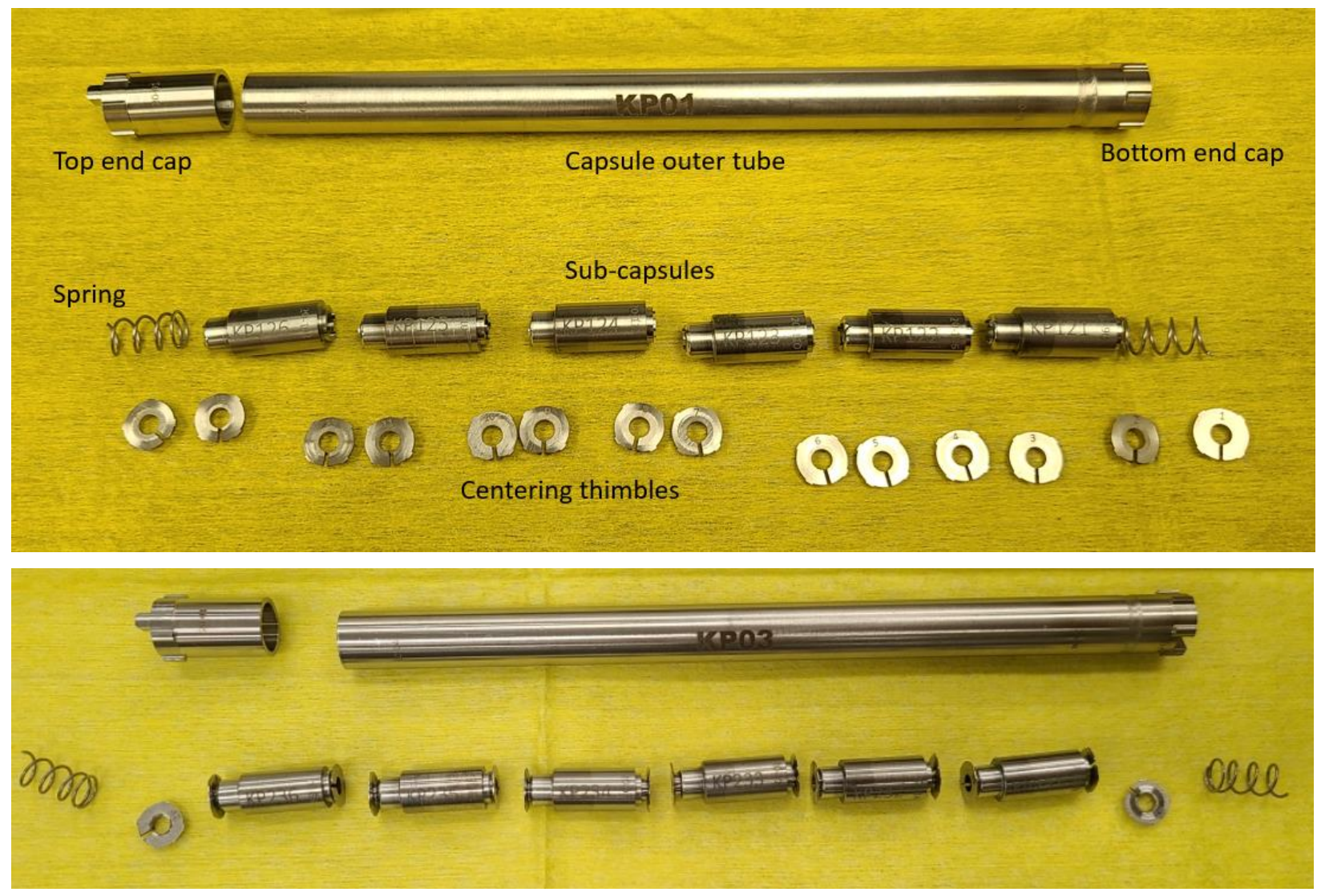

Figure 4. Parts layout of one target assembly: individual parts layout (top) and assembly of centering thimbles and subcapsules (bottom) (Credit: ORNL, US Department of Energy).

All target components were dimensionally inspected and cleaned according to HFIR-approved procedures, drawings, and sketches. After loading the subcapsules, centering thimbles, and compression springs, the target top end caps were orbital welded to the target housings. The targets were then placed inside a sealed container that was evacuated and backfilled with an ultra-high-purity helium/argon mixture (see fill gas in Table 1) three times to ensure a pure environment. The containers were placed inside a glovebox which was also evacuated and backfilled with the same gas that was used in the sealed container, to a pressure equivalent to local atmospheric pressure. A small hole was seal-welded in each target assembly's top end cap using a gas tungsten arc welding procedure. All welds passed visual examination. Each target was then sent for nondestructive examination, which included a helium leak test, hydrostatic compression at a pressure of $7.1 \mathrm{MPa}(1,035 \mathrm{psi})$, mass comparisons before and after hydrostatic compression to ensure that no water penetrated the target assembly, another post-compression helium leak test, dye penetrant inspection, and radiographic inspection. Figure 5 shows a fully welded target, along with a radiographic image of the welds. All target assemblies passed the nondestructive examination. 


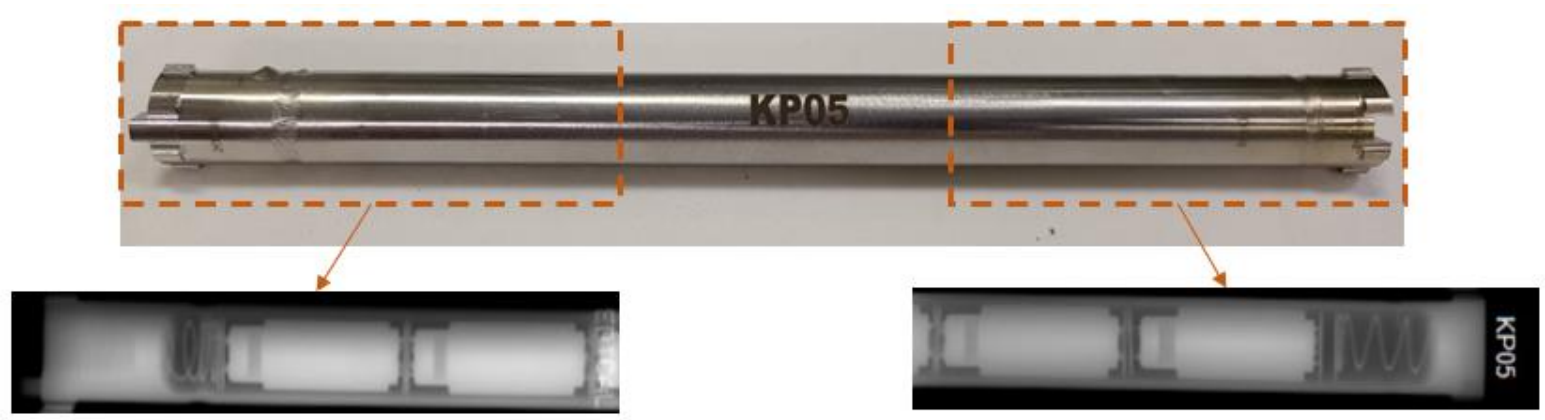

Figure 5. Final target fully welded (top), and radiography of the welds (bottom left and right) (Credit: ORNL, US Department of Energy).

\subsection{LOADING IN THE MINIFUEL BASKET}

The irradiation targets must be loaded into a basket assembly to keep the targets centered within the flow channel in HFIR's small vertical experiment facility (VXF). A total of 9 targets were assembled inside the basket as shown in Figure 1. For this experiment, the $5 \mathrm{KP}$ targets were loaded in the MiniFuel basket (ID MFB) in the irradiation locations shown in Table 1, along with 4 stainless-steel dummy capsules.

\subsection{FABRICATION PACKAGE AND DELIVERY TO HFIR}

Each irradiation experiment requires a fabrication package that is reviewed by an independent design engineer, a lead quality assurance (QA) representative, and a HFIR QA representative before it can be accepted for insertion into HFIR. The fabrication package must satisfy the requirements of the experiment authorization bases document (EABD). The irradiation of miniature fuel specimen experiments falls under document EABD-HFIR-2018-001, Rev. 1 [6], which specifies requirements that the rabbits must satisfy in the following areas:

- thermal safety analyses,

- material certification,

- dimensional inspection,

- cleaning,

- assembly procedure,

- sample loading,

- fill gas,

- welding, and

- nondestructive evaluation.

The fabrication packages for the MFB assembly and the KP targets were reviewed and approved by all parties and accepted by HFIR on May 11, 2021 and June 21, 2021, respectively. The final signed acceptance page of the targets' EABD is provided in Appendix A. The loaded MFB was inserted into HFIR's small VXF-11 position starting in cycle 493 (June 2021). 


\section{SUMMARY AND CONCLUSIONS}

Five MiniFuel targets containing TRISO compacts were inserted in HFIR to start irradiation in cycle 493 (commencing on June 29, 2021); the irradiation will be completed after 4 HFIR cycles i.e., at the end of cycle 496, which is expected to end on January 7, 2022. Ultimately, the particle failure proportion and associated failure mechanisms will be determined through well-established post-irradiation examination (PIE) techniques. The failure and fission product release mechanisms may include kernel migration, interaction of fission products with coating layers, and athermal and diffusive release of fission products.

\section{REFERENCES}

[1] P.A. Demkowicz, B. Liu, J.D. Hunn, Coated particle fuel: Historical perspectives and current progress, Journal of Nuclear Materials, vol. 515, pages 434-450, 2019.

[2] D.A. Petti, J. Buongiorno, J.T. Maki, R.R. Hobbins, G.K. Miller, Key differences in the fabrication, irradiation and high temperature accident testing of US and German TRISO-coated particle fuel, and their implications on fuel performance, Nuclear Engineering and Design, vol. 222, pages 281-297, 2003.

[3] R.C. Gallagher, Z. Wallen, C.M. Petrie, T. Gerczak, A.G. Le Coq, K. Smith, J. Harp, K.D. Linton, B. Collin, and R. Latta, Analysis and Design of High-Power TRISO Fuel Compact Irradiation in HFIR, ORNL/TM-2020/1658, Oak Ridge National Laboratory, Oak Ridge, TN, June 2021.

[4] T.J. Gerczak, A.K. Kercher, A.T. Schumacher, G.W. Helmreich, M. Trammell, Fabrication of MiniFuel Compacts for High-Power Irradiation Testing of TRISO Fuel, ORNL/SPR-2020/1778, Oak Ridge National Laboratory, Oak Ridge, TN, November 2020.

[5] T.J. Gerczak, G.W. Helmreich, C.A. Hobbs, A.K. Kercher, R. Latta, Preirradiation Characterization of MiniFuel Compacts for High-Power Irradiation Testing of TRISO Fuel, ORNL/TM-2021/5, Oak Ridge, TN, January 2021.

[6] Experiment Authorization Bases Document, Irradiation of Miniature Fuel Specimens in the Inner Small VXF Positions, EABD-HFIR-2018-001 Rev. 1, May 2021. 


\section{APPENDIX A. FABRICATION REQUEST SHEETS}





\section{APPENDIX A. FABRICATION REQUEST SHEETS}

Target ID:

radiation Conditions

Irradiation Location $(R, A)$

Number cycles

First Cycle Goa

Fill Gas

Irradiation Temperature

Holder assembly drawing

Holder assembly welding drawing

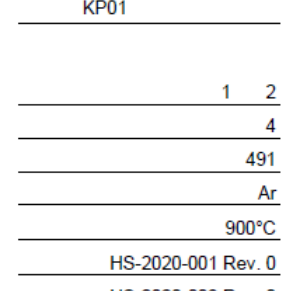

HS-2020-003 Rev. 0

Holder Assembly

Holder Assembly

Holder

Holder

End cap

End cap

Tube

D
1
$\omega$

Insulator disk (list total \# and mass)

Coated Particle Fuel Compact

\begin{tabular}{l|l|l|l|} 
Drawing & Rev. & Part & Material \\
\hline
\end{tabular}

\begin{tabular}{|c|c|c|}
\hline \multirow[b]{3}{*}{ Performed by: } & \multirow{2}{*}{ Approvals } & \multirow{3}{*}{ 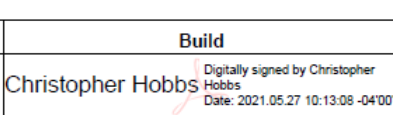 } \\
\hline & & \\
\hline & \begin{tabular}{|l} 
Annabelle Le Coq \\
Digitally signed by Annabelle Le \\
Date: 2021.05 .27 09:02:41 -04'
\end{tabular} & \\
\hline Checked b & 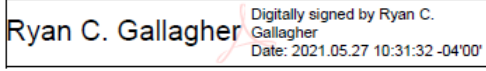 & David Bryant \\
\hline
\end{tabular}

Spacer

Disk

\begin{tabular}{|c|c|c|c|c|c|}
\hline Drawing & Rev. & Part & Material & MAT \\
\hline S17-14-CER_FUEL & 2 & 1 & Moly & 2109 \\
\hline S17-14-CER_FUEL & 2 & 1 & Moly & 21093 \\
S17-14-CER_FUEL & 2 & 1 & Moly & 210 \\
\hline S17-14-CER_FUEL & 2 & 2 & Moly & 21154 \\
\hline HS-2020-001 & 0 & 3 & Moly & 2110 \\
\hline HS-2020-001 & 0 & 6 & SiC & 208 \\
\hline HS-2020-001 & 0 & 7 & Grafoil & 198 \\
\hline HS-2020-001 & 0 & 5 & $\begin{array}{c}\text { UCO } \\
\text { UO2 }\end{array}$ & 21175 \\
\hline HS-2020-001 & 0 & 2 & SiC & 20863 \\
\hline HS-2020-001 & 0 & 4 & Graphite & 21143 \\
\hline
\end{tabular}

\begin{tabular}{|c|c|c|c|c|c|c|c|c|c|c|c|c|c|c|}
\hline & & & & & $\overline{\mathbf{S}}=$ sub-assen & blly position & & & & & & & \\
\hline & & 1 & 2 & 3 & 4 & 5 & 6 & 1 & 2 & 3 & 4 & 5 & 6 & \\
\hline & & \multicolumn{6}{|c|}{ Component IDs for each holder ID } & \multicolumn{7}{|c|}{ Component mass (g) for each holder ID } \\
\hline MAT IR & FAB IR & KP121 & KP122 & KP123 & KP124 & KP125 & KP126 & KP121 & KP122 & KP123 & KP124 & KP125 & KP126 & All \\
\hline 21093 & 21162 & $20-96$ & $\mathrm{~N} / \mathrm{A}$ & $\mathrm{N} / \mathrm{A}$ & N/A & $\mathrm{N} / \mathrm{A}$ & $\mathrm{N} / \mathrm{A}$ & 7.7307 & N/A & $\mathrm{N} / \mathrm{A}$ & N/A & N/A & $\mathrm{N} / \mathrm{A}$ & 7.7307 \\
\hline 21093 & 21167 & N/A & $20-106$ & $20-110$ & N/A & $20-103$ & $20-102$ & N/A & 7.8502 & 7.8741 & N/A & 7.8955 & 7.8223 & 31.442 \\
\hline 21093 & 21168 & N/A & N/A & N/A & $20-112$ & N/A & N/A & N/A & $\mathrm{N} / \mathrm{A}$ & N/A & 7.9701 & $\mathrm{~N} / \mathrm{A}$ & $\mathrm{N} / \mathrm{A}$ & 7.9701 \\
\hline 21154 & 21154 & $20-07$ & $20-08$ & $20-09$ & $20-10$ & 20-11 & $20-12$ & 0.5057 & 0.5207 & 0.5215 & 0.5018 & 0.5281 & 0.5112 & 3.0890 \\
\hline 21100 & 21151 & $20-04$ & $20-05$ & $20-06$ & $20-07$ & $20-08$ & $20-09$ & 2.6305 & 2.6450 & 2.6361 & 2.6348 & 2.6227 & 2.6331 & 15.8022 \\
\hline 20863 & 21144 & 001 & 002 & 003 & 004 & 005 & 006 & 0.0369 & 0.0371 & 0.0351 & 0.0369 & 0.0370 & 0.0373 & 0.2203 \\
\hline 19812 & 19812 & $5 \mathrm{pcs}$ & $5 \mathrm{pcs}$ & $5 \mathrm{pcs}$ & $5 \mathrm{pcs}$ & $5 \mathrm{pcs}$ & $5 \mathrm{pcs}$ & 0.0145 & 0.0145 & 0.0145 & 0.0145 & 0.0145 & 0.0145 & 0.0870 \\
\hline \multirow[t]{2}{*}{21175} & 21175 & LEU09-M01E & $\mathrm{N} / \mathrm{A}$ & LEU09-M07E & N/A & LEU09-M09E & $\mathrm{N} / \mathrm{A}$ & 0.0623 & $\mathrm{~N} / \mathrm{A}$ & 0.0613 & N/A & 0.0601 & N/A & 0.1837 \\
\hline & & N/A & LEU11-M01B & \begin{tabular}{|l|}
$\mathrm{N} / \mathrm{A}$ \\
\end{tabular} & LEU11-M05B & N/A & LEU11-M14B & N/A & 0.0673 & $\mathrm{~N} / \mathrm{A}$ & 0.0673 & $\mathrm{~N} / \mathrm{A}$ & 0.0667 & 0.2013 \\
\hline \multirow[t]{2}{*}{20863} & 21185 & $20-07$ & $20-09$ & $20-11$ & $20-13$ & $20-15$ & $20-17$ & 0.0671 & 0.0641 & 0.0620 & 0.0634 & 0.0578 & 0.0607 & 0.3751 \\
\hline & & $20-08$ & $20-10$ & 20-12 & 20-14 & 20-16 & $20-18$ & 0.0622 & 0.0617 & 0.0614 & 0.0627 & 0.0629 & 0.0605 & 0.3714 \\
\hline 21143 & 21143 & $20-04$ & $20-05$ & $20-06$ & $20-07$ & $20-08$ & $20-09$ & 0.0382 & 0.0386 & 0.0386 & \begin{tabular}{|l|l|}
0.0379 \\
\end{tabular} & 0.0388 & 0.0395 & 0.2316 \\
\hline
\end{tabular}

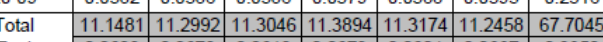

Graphite 


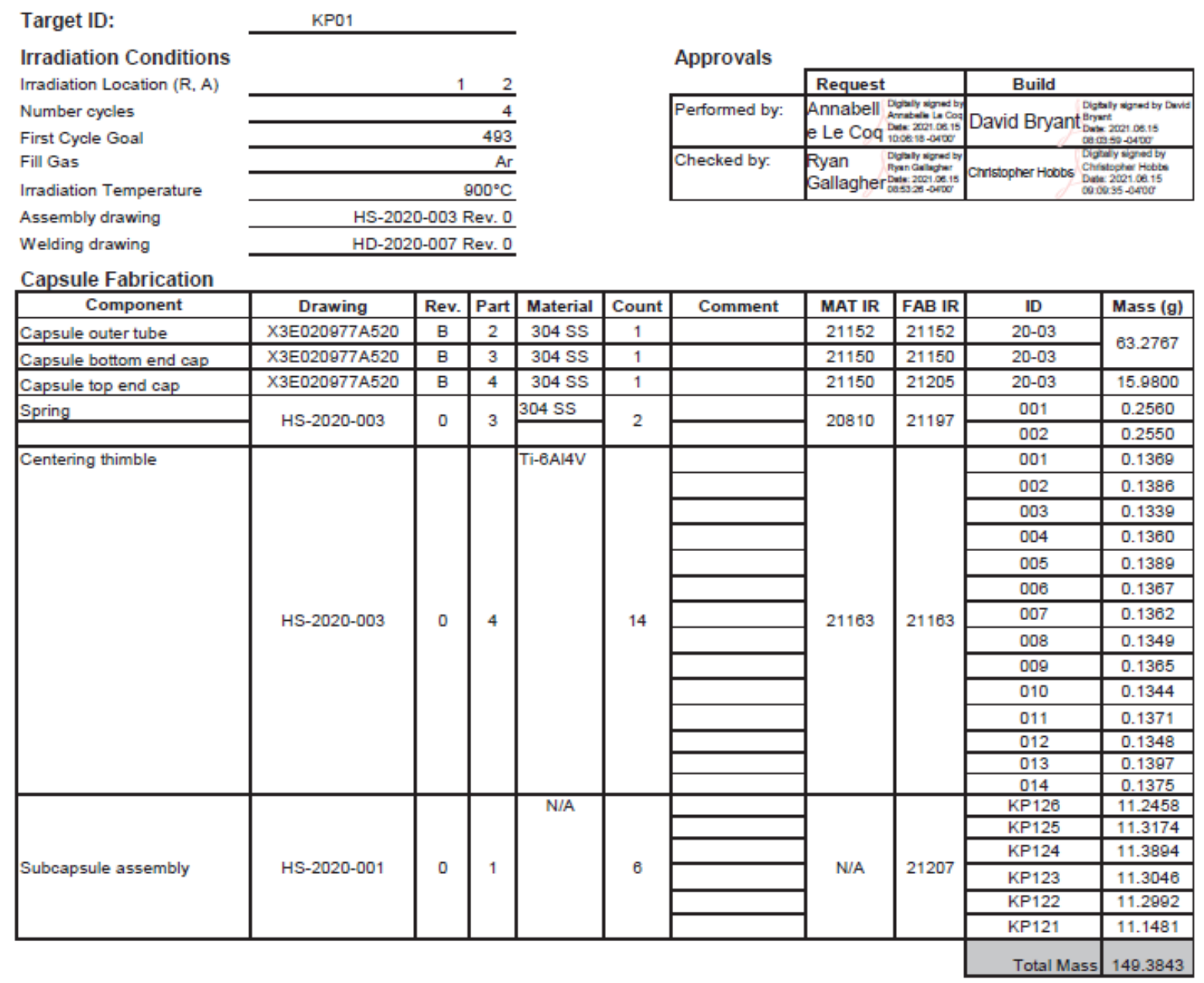

Holder Sub-Assemblies
\begin{tabular}{|l|c|c|c|c|}
\hline Holder ID & $\begin{array}{c}\text { S = Sub-Assemb'y } \\
\text { Position }\end{array}$ & $\begin{array}{c}\text { R-A-S } \\
\text { (R = Radial target position, } \mathbf{A}=\text { Axial target position) }\end{array}$ & $\begin{array}{c}\text { Holder } \\
\text { diameter (mm) }\end{array}$ & Initial \\
\hline KP126 & 6 & $1-2-6$ & 9.29 & DB \\
\hline KP125 & 5 & $1-5$ & 9.31 & DB \\
\hline KP124 & 4 \\
\hline KP123 & 3 \\
\hline KP122 & 2 \\
\hline KP121 & 1 & $1-2-4$ & 9.35 & DB \\
\hline
\end{tabular}


Target ID:

Irradiation Conditions

Irradiation Location $(R, A)$

Number cycles

First Cycle Goal

Fill Gas

Irradiation Temperature

Holder assembly drawing

Holder assembly welding drawing

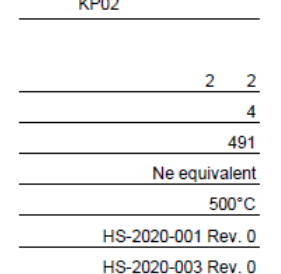

(10)

Component

\begin{tabular}{ll}
\hline Holder \\
\hline Holder \\
\hline
\end{tabular}

Holder

Holder

End cap

End

\begin{tabular}{|l|}
\hline Tube \\
\hline Thermometry \\
\hline
\end{tabular}

Themometry

insulator disk (ilist total \# and mass)

oated Particle Fuel Compact

HS-2020-001

Spacer

ن̀
Approvals

\begin{tabular}{|c|c|c|}
\hline \multirow[b]{2}{*}{ Performed by: } & Request & Build \\
\hline & Annabelle Le Coq $\begin{array}{l}\text { Digitally signed by Annabelle Le coq } \\
\text { Date: 2021.05.27 09:04:22-0400 }\end{array}$ & 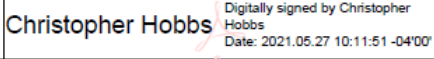 \\
\hline Checked by: & $\begin{array}{l}\text { Ryan C. Gallagher } \\
\text { Digitally signed by Ryan C. Gallagher } \\
\text { Date: 2021.05.27 10:35:54 -040 } 00^{\circ}\end{array}$ & David Bryant \\
\hline
\end{tabular}

$S=$ sub-assembly position

\begin{tabular}{|c|c|c|c|c|c|c|c|c|c|c|c|c|}
\hline \multirow{2}{*}{\multicolumn{12}{|c|}{$\mathbf{S}=$ sub-assembly position }} & \\
\hline 1 & 2 & 3 & 4 & \begin{tabular}{|l|l|}
5 \\
\end{tabular} & & & & & & & 6 & \\
\hline \multicolumn{6}{|c|}{ Component IDs for each holder ID } & \multicolumn{7}{|c|}{ Component mass (g) for each holder ID } \\
\hline KP221 & KP222 & KP223 & КР224 & KP225 & KP226 & KP221 & KP222 & KP223 & KP224 & KP225 & KP226 & All \\
\hline 20-135 & N/A & N/A & $\mathrm{N} / \mathrm{A}$ & $\mathrm{N} / \mathrm{A}$ & N/A & 8.5492 & $\mathrm{~N} / \mathrm{A}$ & N/A & $\mathrm{N} / \mathrm{A}$ & $\mathrm{N} / \mathrm{A}$ & $\mathrm{N} / \mathrm{A}$ & 8.5492 \\
\hline N/A & $20-113$ & $\mathrm{~N} / \mathrm{A}$ & N/A & N/A & $20-117$ & $\mathrm{~N} / \mathrm{A}$ & 8.0505 & $\mathrm{~N} / \mathrm{A}$ & N/A & $\mathrm{N} / \mathrm{A}$ & 8.0089 & 16.0594 \\
\hline N/A & $\mathrm{N} / \mathrm{A}$ & $20-140$ & N/A & $20-136$ & N/A & N/A & $\mathrm{N} / \mathrm{A}$ & 8.5704 & $\mathrm{~N} / \mathrm{A}$ & 8.6332 & N/A & 17.2036 \\
\hline N/A & N/A & $\mathrm{N} / \mathrm{A}$ & $20-123$ & $\mathrm{~N} / \mathrm{A}$ & N/A & N/A & N/A & $\mathrm{N} / \mathrm{A}$ & 7.9940 & $\mathrm{~N} / \mathrm{A}$ & N/A & 7.9940 \\
\hline $20-13$ & $20-14$ & $20-15$ & $20-16$ & $20-41$ & $20-18$ & 0.5186 & 0.5217 & 0.5258 & 0.5307 & 0.5268 & 0.5281 & 3.1517 \\
\hline $20-10$ & $20-11$ & $20-12$ & $20-13$ & $20-34$ & $20-15$ & 2.6149 & 2.6339 & 2.6360 & 2.6245 & 2.6346 & 2.6160 & 15.7599 \\
\hline 006 & 007 & 008 & 009 & 031 & 011 & 0.0373 & 0.0365 & \begin{tabular}{|l|}
0.0372 \\
\end{tabular} & 0.0374 & 0.0370 & 0.0375 & 0.2229 \\
\hline $5 \mathrm{pcs}$ & $5 \mathrm{pcs}$ & $5 \mathrm{pcs}$ & $5 \mathrm{pcs}$ & $5 \mathrm{pcs}$ & $5 \mathrm{pcs}$ & 0.0145 & \begin{tabular}{|l|}
0.0145 \\
\end{tabular} & \begin{tabular}{|l|}
0.0145 \\
\end{tabular} & 0.0145 & \begin{tabular}{|l|l|}
0.0145 \\
\end{tabular} & \begin{tabular}{|l|l|}
0.0145 \\
\end{tabular} & 0.0870 \\
\hline LEUO9-M10E & N/A & LEU09-M14E & $\mathrm{N} / \mathrm{A}$ & LEU09-M16E & $\mathrm{N} / \mathrm{A}$ & 0.0625 & N/A & \begin{tabular}{|l|l|}
0.0618 \\
\end{tabular} & $\mathrm{~N} / \mathrm{A}$ & 0.0618 & $\mathrm{~N} / \mathrm{A}$ & 0.1861 \\
\hline $\mathrm{N} / \mathrm{A}$ & NUCO425-08T-M02F & $\mathrm{N} / \mathrm{A}$ & NUCO425-08T-M03F & N/A & $\begin{array}{l}\text { NUC 0425-08T-M04F } \\
\end{array}$ & $\mathrm{N} / \mathrm{A}$ & 0.0598 & N/A & 0.0592 & $\mathrm{~N} / \mathrm{A}$ & 0.0601 & 0.1791 \\
\hline $20-19$ & $20-21$ & $20-23$ & $20-25$ & $20-68$ & $20-29$ & 0.0627 & 0.0615 & 0.0637 & 0.0610 & 0.0626 & 0.0635 & 0.3750 \\
\hline $20-20$ & $20-22$ & $20-24$ & $20-26$ & $20-69$ & $20-30$ & 0.0621 & \begin{tabular}{|l|}
0.0638 \\
\end{tabular} & \begin{tabular}{|l|}
0.0625 \\
\end{tabular} & 0.0629 & 0.0612 & 0.0638 & 0.3763 \\
\hline $20-10$ & $20-11$ & $20-12$ & $20-13$ & $20-34$ & $20-15$ & 0.0392 & 0.0392 & \begin{tabular}{|l|l|}
0.0387 \\
\end{tabular} & 0.0390 & \begin{tabular}{|l|l|}
0.0391 \\
\end{tabular} & \begin{tabular}{|l|l|}
0.0383 \\
\end{tabular} & 0.2335 \\
\hline
\end{tabular}

\begin{tabular}{|l|c|c|c|c|c|c|c|}
\hline & 0.0392 & 0.0392 & 0.0387 & 0.0390 & 0.0391 & 0.0383 & 0.2335 \\
\hline Total & 11.9610 & 114814 & 120106 & 114232 & 120 & 1 & \\
\hline
\end{tabular}

\begin{tabular}{|l|l|l|l|l|l|l|l|}
\hline 11.9610 & 11.4814 & 12.0106 & 11.4232 & 12.0708 & 11.4307 & 70.3777 \\
\hline 0.0625 & 0.0598 & 0.0618 & 0.0592 & 0.0618 & 0.0601 & 0.3652 \\
\hline
\end{tabular} 
Target ID:

Irradiation Conditions

Irradiation Location (R, A)

Number cycles

First Cycle Goal

Fill Gas

Irradiation Temperature

Assembly drawing

Welding drawing

Capsule Fabrication

\begin{tabular}{|c|c|c|c|c|c|c|c|c|c|c|}
\hline Component & Drawing & Rev. & Part & Material & Count & Comment & MAT IR & FAB IR & ID & Mass (g) \\
\hline Capsule outer tube & X3E020977A520 & $\mathrm{B}$ & 2 & $304 \mathrm{SS}$ & 1 & & 21152 & 21152 & $20-07$ & \multirow{2}{*}{62.9936} \\
\hline Capsule bottom end cap & X3E020977A520 & $B$ & 3 & $304 \mathrm{SS}$ & 1 & & 21150 & 21150 & $20-07$ & \\
\hline Capsule top end cap & X3E020977A520 & $B$ & 4 & $304 \mathrm{SS}$ & 1 & & 21150 & 21205 & $20-07$ & 15.8995 \\
\hline \multirow[t]{2}{*}{ Spring } & \multirow{2}{*}{ HS-2020-003 } & \multirow{2}{*}{0} & \multirow{2}{*}{3} & \multirow[t]{2}{*}{304 SS } & \multirow{2}{*}{2} & & \multirow{2}{*}{20810} & \multirow{2}{*}{21197} & 003 & 0.2600 \\
\hline & & & & & & & & & 004 & 0.2650 \\
\hline \multirow[t]{14}{*}{ Centering thimble } & \multirow{14}{*}{ HS-2020-003 } & \multirow{14}{*}{0} & \multirow{14}{*}{4} & \multirow[t]{14}{*}{ Ti-6Al4V } & \multirow{14}{*}{14} & & \multirow{14}{*}{21163} & \multirow{14}{*}{21163} & 015 & 0.1358 \\
\hline & & & & & & & & & 016 & 0.1357 \\
\hline & & & & & & & & & 017 & 0.1353 \\
\hline & & & & & & & & & 018 & 0.1353 \\
\hline & & & & & & & & & 019 & 0.1373 \\
\hline & & & & & & & & & 020 & 0.1376 \\
\hline & & & & & & & & & 021 & 0.1389 \\
\hline & & & & & & & & & 022 & 0.1364 \\
\hline & & & & & & & & & 023 & 0.1355 \\
\hline & & & & & & & & & 024 & 0.1383 \\
\hline & & & & & & & & & 025 & 0.1377 \\
\hline & & & & & & & & & 026 & 0.1350 \\
\hline & & & & & & & & & 027 & 0.1357 \\
\hline & & & & & & & & & 028 & 0.1380 \\
\hline \multirow{6}{*}{ Subcapsule assembly } & \multirow{6}{*}{ HS-2020-001 } & \multirow{6}{*}{0} & \multirow{6}{*}{1} & \multirow[t]{6}{*}{$\mathrm{N} / \mathrm{A}$} & \multirow{6}{*}{6} & & \multirow{6}{*}{ N/A } & \multirow{6}{*}{21207} & $\mathrm{KP} 226$ & 11.4307 \\
\hline & & & & & & & & & $\mathrm{KP} 225$ & 12.0708 \\
\hline & & & & & & & & & KP224 & 11.4232 \\
\hline & & & & & & & & & KP223 & 12.0106 \\
\hline & & & & & & & & & KP222 & 11.4814 \\
\hline & & & & & & & & & KP221 & 11.9610 \\
\hline
\end{tabular}

Holder Sub-Assemblies

\begin{tabular}{|c|c|c|c|c|}
\hline Holder ID & $\begin{array}{c}\text { S = Sub-Assembly } \\
\text { Position }\end{array}$ & $(\mathbf{R}=$ Radial target position, $\mathbf{A}=$ Axial target position) & $\begin{array}{c}\text { Holder } \\
\text { diameter (mm) }\end{array}$ & Initial \\
\hline KP226 & 6 & $2-2-6$ & 9.35 & DB \\
\hline KP225 & 5 & $2-2-5$ & 9.60 & DB \\
\hline KP224 & 4 \\
\hline KP223 & 3 & $2-2-4$ & 9.37 & DB \\
\hline KP222 & 2 & $2-2-3$ & 9.60 & DB \\
\hline KP221 & 1 & $2-2-2$ & 9.37 & DB \\
\hline
\end{tabular}

Approvals

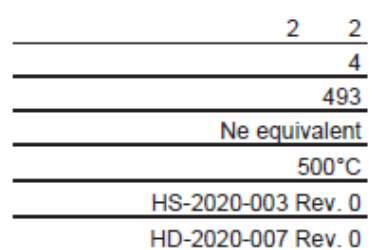

\begin{tabular}{|c|c|c|}
\hline & Request & Build \\
\hline Performed by: & 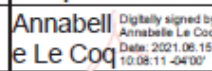 & 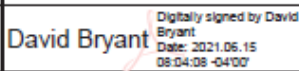 \\
\hline Checked by: & 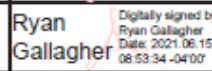 & $\begin{array}{l}\text { Christopher } \\
\text { Hobbs }\end{array}$ \\
\hline
\end{tabular}


Target ID:

Irradiation Conditions

Irradiation Location (R, A)

Number cycles

First Cycle Goal

Fill Gas

Irradiation Temperature

Holder assembly drawing

Holder assembly welding drawing
KP03

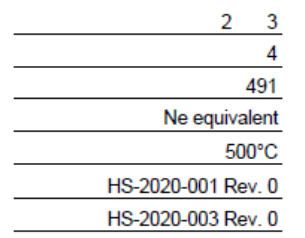

Approvals

\begin{tabular}{|c|c|c|}
\hline \multirow{3}{*}{$\begin{array}{l}\text { erformed by: } \\
\text { Checked by: }\end{array}$} & Request & Build \\
\hline & \begin{tabular}{|l} 
Annabelle Le Coq \\
Digtally signed by Annabelle Le \\
Date: \\
Date: 2021.05 .27 \\
$08: 56: 43-040^{\circ}$
\end{tabular} & Christopher Hobbs \\
\hline & $\begin{array}{c}\text { Ryan C. Gallagher Gigitally signed by Ryan C. } \\
\text { Date: } 2021.05 .27 \\
\text { Da: } 10: 42: 45-04^{*} 00\end{array}$ & David Bryant \\
\hline
\end{tabular}

Holder Assembly

\begin{tabular}{|l|l|l|l|l|l|}
\hline & \multicolumn{2}{|c|}{$\mathbf{S}=$ sub-assembly position } \\
\hline 1 & 2 & 3 & 4
\end{tabular}

\begin{tabular}{|c|c|c|c|c|c|c|c|c|c|c|c|c|c|c|c|c|c|c|c|}
\hline \multicolumn{7}{|l|}{ Holder Assembly } & \multicolumn{6}{|c|}{ Component IUs for each holder ID } & \multicolumn{7}{|c|}{ Component mass (g) for each holder ID } \\
\hline Component & Drawing & Rev. & Part & Material & MAT IR & FAB IR & KP231 & KP232 & KP233 & KP234 & KP235 & KP236 & KP231 & KP232 & KP233 & KP234 & KP235 & KP236 & All \\
\hline Holder & S17-14-CER_FUEL & 2 & 1 & Moly & 21093 & 21158 & $20-128$ & N/A & N/A & $\mathrm{N} / \mathrm{A}$ & N/A & $\mathrm{N} / \mathrm{A}$ & 8.2680 & N/A & $\mathrm{N} / \mathrm{A}$ & $\mathrm{N} / \mathrm{A}$ & N/A & N/A & 8.2680 \\
\hline Holder & S17-14-CER_FUEL_ & 2 & 1 & Moly & 21093 & 21170 & N/A & $20-124$ & N/A & N/A & N/A & N/A & N/A & 8.1646 & N/A & N/A & N/A & N/A & 8.1646 \\
\hline Holder & S17-14-CER_FUEL & 2 & 1 & Moly & 21093 & 21168 & N/A & $\mathrm{N} / \mathrm{A}$ & $20-114$ & N/A & N/A & N/A & N/A & N/A & 7.9140 & $\mathrm{~N} / \mathrm{A}$ & N/A & N/A & 7.9140 \\
\hline Holder & S17-14-CER_FUEL & 2 & 1 & Moly & 21093 & \begin{tabular}{|l|l|}
21166 \\
\end{tabular} & N/A & $\mathrm{N} / \mathrm{A}$ & N/A & $20-92$ & N/A & $\mathrm{N} / \mathrm{A}$ & N/A & $\mathrm{N} / \mathrm{A}$ & $\mathrm{N} / \mathrm{A}$ & 7.7187 & N/A & N/A & 7.7187 \\
\hline Holder & S17-14-CER_FUEL & 2 & 1 & Moly & 21154 & 21164 & N/A & N/A & N/A & $\mathrm{N} / \mathrm{A}$ & $20-81$ & N/A & N/A & N/A & $N / A$ & $\mathrm{~N} / \mathrm{A}$ & 7.3943 & N/A & 7.3943 \\
\hline Holder & S17-14-CER_FUEL & 2 & 1 & Moly & 21154 & 21156 & N/A & $\mathrm{N} / \mathrm{A}$ & N/A & $N / A$ & $\mathrm{~N} / \mathrm{A}$ & $20-68$ & N/A & N/A & $N / A$ & N/A & N/A & 6.8537 & 6.8537 \\
\hline End cap & S17-14-CER_FUEL & 2 & 2 & Moly & 21154 & 21154 & $20-19$ & $20-20$ & $20-21$ & $20-22$ & $20-23$ & $20-24$ & 0.5189 & 0.5151 & 0.5230 & 0.5148 & 0.5216 & 0.5126 & 3.1060 \\
\hline Tube & HS-2020-001 & 0 & 3 & Moly & 21100 & 21151 & $20-16$ & $20-17$ & $20-18$ & $20-19$ & $20-20$ & $20-21$ & 2.6360 & 2.6395 & 2.6378 & 2.6527 & 2.6402 & 2.6360 & 15.8422 \\
\hline Thermometry & HS-2020-001 & 0 & 6 & $\mathrm{SiC}$ & 20863 & 21144 & 013 & 014 & 015 & 016 & 017 & 018 & 0.0365 & \begin{tabular}{|l|l|}
0.0377 \\
\end{tabular} & 0.0378 & \begin{tabular}{|l|l|}
0.0367 \\
\end{tabular} & \begin{tabular}{|l|l|}
0.0374 \\
\end{tabular} & 0.0375 & 0.2236 \\
\hline Insulator disk (list total \# and mass) & HS-2020-001 & 0 & 7 & Grafoil & 19812 & 19812 & $5 \mathrm{pcs}$ & $5 \mathrm{pcs}$ & $5 \mathrm{pcs}$ & $5 \mathrm{pcs}$ & $5 \mathrm{pcs}$ & $5 \mathrm{pcs}$ & 0.0145 & 0.0145 & 0.0145 & 0.0145 & 0.0145 & 0.0145 & 0.0870 \\
\hline Coated Particle Fuel Compact & HS-2020-001 & 0 & 5 & UCO & 21175 & 21175 & LEU09-M17E & LEU09-M19E & LEU09-M21E & LEU09-M22E & LEU09-M24E & LEU09-M25E & 0.0614 & 0.0618 & 0.0628 & 0.0607 & 0.0616 & 0.0613 & 0.3696 \\
\hline Spacer & HS-2020-001 & 0 & 2 & $\mathrm{SiC}$ & 20863 & 21185 & $20-32$ & $20-34$ & $20-36$ & $20-38$ & $20-40$ & $20-42$ & 0.0653 & 0.0621 & 0.0640 & 0.0657 & 0.0651 & 0.0576 & 0.3798 \\
\hline & & & & & & & $20-33$ & $20-35$ & $20-37$ & $20-39$ & $20-41$ & $20-43$ & 0.0650 & 0.0653 & 0.0635 & 0.0641 & 0.0604 & 0.0635 & 0.3818 \\
\hline Disk & HS-2020-001 & 0 & 4 & Graphite & 21143 & 21143 & $20-16$ & $20-17$ & $20-18$ & $20-19$ & $20-20$ & $20-34$ & 0.0394 & 0.0389 & 0.0391 & 0.0389 & 0.0388 & 0.0391 & 0.2342 \\
\hline
\end{tabular}

\begin{tabular}{|l|l|l|l|l|l|l|l|l|l|}
\hline Total & 11.7050 & 11.5995 & 11.3565 & 11.1668 & 10.8339 & 10.2758 & 66.9375 \\
\hline
\end{tabular}

\begin{tabular}{l|l|l|l|l|l|l|l|} 
Fuel & 11.7050 & 11.5995 & 11.3565 & 11.1668 & 10.8339 & 10.2758 & 66.9375 \\
\cline { 2 - 8 } & 0.0614 & 0.0618 & 0.0628 & 0.0607 & 0.0616 & 0.0613 & 0.3696 \\
\hline
\end{tabular} 


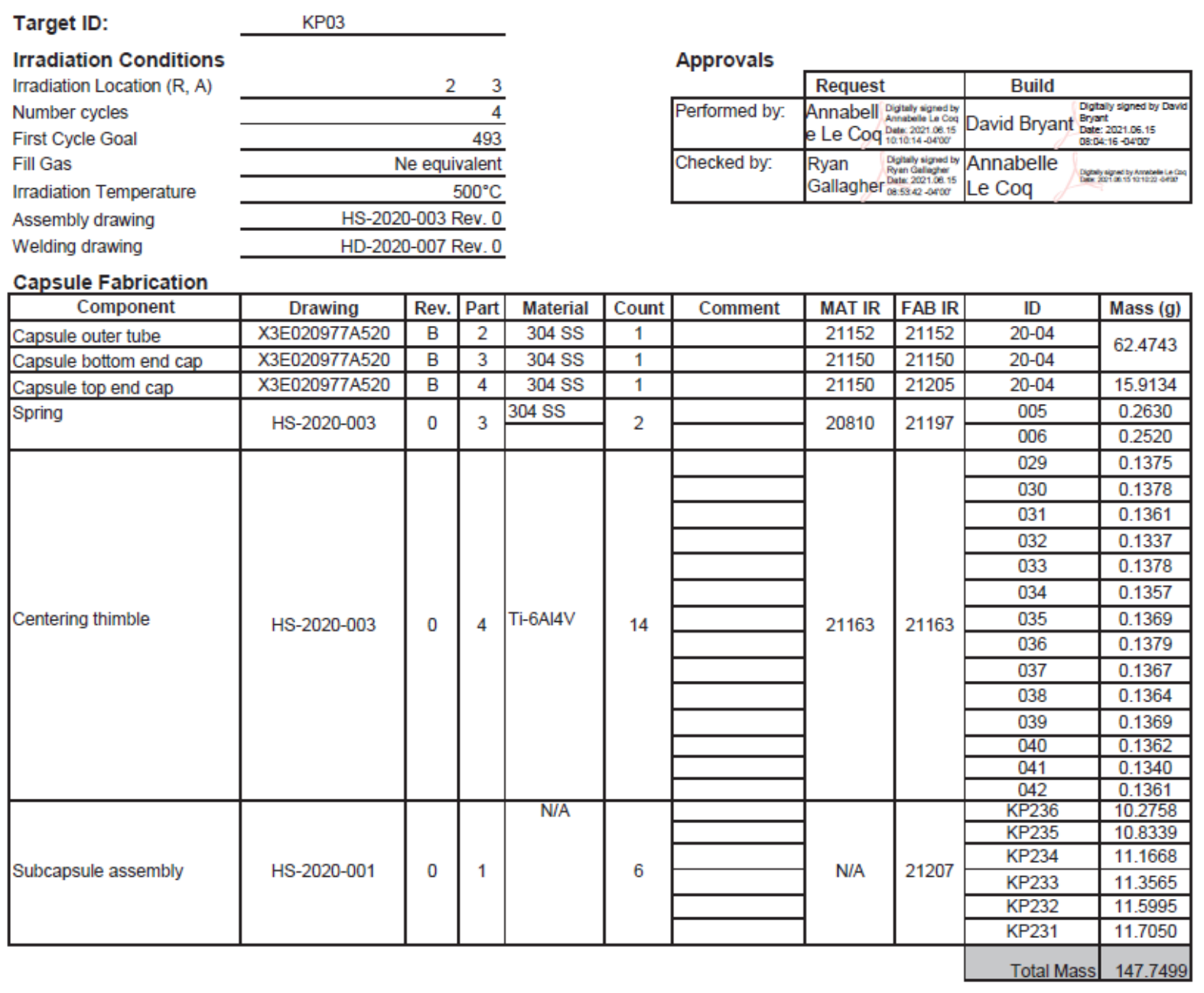

Holder Sub-Assemblies
\begin{tabular}{|c|c|c|c|c|}
\hline \multirow{2}{*}{ Holder ID } & $\begin{array}{c}\text { S= Sub-Assembly } \\
\text { Position }\end{array}$ & $\begin{array}{c}\text { R-A-S } \\
\text { (R = Radial target position, A = Axial target position) }\end{array}$ & $\begin{array}{c}\text { Holder } \\
\text { diameter (mm) }\end{array}$ & Initial \\
\hline KP236 & 6 \\
\hline KP235 & 5 \\
\hline KP234 & 4 \\
\hline KP233 & 3 \\
\hline KP232 & 2 \\
\hline KP231 & 1 \\
\hline
\end{tabular}




\section{Target ID:}

Irradiation Conditions

Irradiation Location ( $R$, A

Number cycles

Fill Gas

Irradiation Temperature

Holder assembly drawing

Holder assembly welding drawing

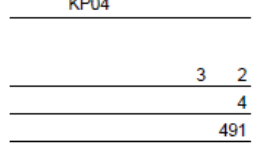

$\begin{array}{r}\text { Ne equivalent } \\ 700^{\circ} \mathrm{C} \\ \hline \text { HS-2020-001 Rev } 0\end{array}$

HS-2020-003 Rev. 0

Holder Assembly

Holder Assembly
Component

Holder

Holder

Holder

End cap

Tube

Thermometry

Insulator disk (list total \# and mass)
Coated Particle Fuel Compact

Spacer

Disk

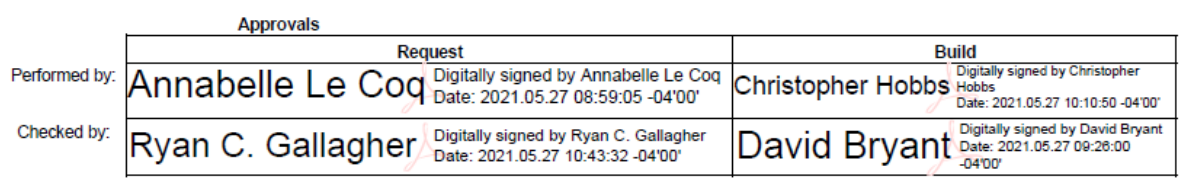

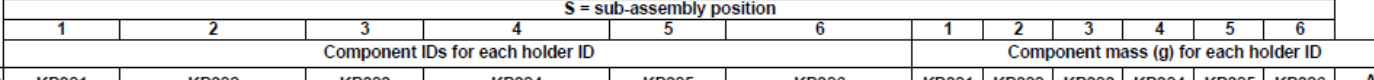
\begin{tabular}{|l|c|c|c|c|c|c|c|c|c|c|c|c|}
\hline KP321 & KP322 & KP323 & KP324 & KP325 & KP326 & KP321 & KP322 & KP323 & KP324 & KP325 & KP326 & All \\
\hline $20-79$ & N/A & N/A & N/A & N/A & N/A & 72960 & N/A & N/A & N NA & N/A & N/A & 72960 \\
\hline
\end{tabular}

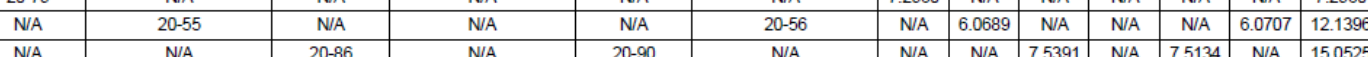

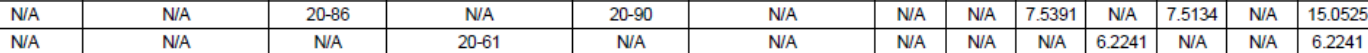
\begin{tabular}{l|l|l|l|l|l|l|l|l|l|l|l|l|}
\hline $20-25$ & $20-26$ & $20-27$ & $20-28$ & $20-29$ & $20-31$ & 0.5192 & 0.5165 & 0.5209 & 0.5320 & 0.5142 & 0.5208 & 3.1236 \\
\hline
\end{tabular} \begin{tabular}{|c|c|c|c|c|c|c|c|c|c|c|c|c|c|}
\hline 019 & 020 & 021 & 022 & 023 & 024 & 0.0369 & 0.0367 & 0.0369 & 0.0366 & 0.0372 & 0.0367 & 0.2210 \\
\hline
\end{tabular}

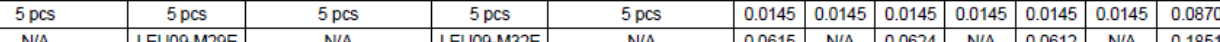
\begin{tabular}{|l|l|l|l|l|l|l|l|l|l|l|l|l|}
\hline N/A & LEU09-M29E & N/A & LEU09-M32E & N/A & 0.0615 & N/A & 0.0624 & N/A & 0.0612 & N/A & 0.1851 \\
\hline
\end{tabular}

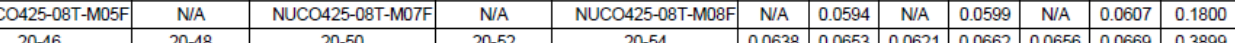
\begin{tabular}{|l|l|l|l|l|l|l|l|l|l|l|l|}
\hline $20-46$ & $20-48$ & $20-50$ & $20-52$ & $20-54$ & 0.0638 & 0.0653 & 0.0621 & 0.0662 & 0.0656 & 0.0669 & 0.3899 \\
\hline $20-47$ & $20-49$ & $20-51$ & $20-53$ & $20-55$ & 0.0643 & 0.0650 & 0.0653 & 0.0633 & 0.0619 & 0.0647 & 0.3845 \\
\hline
\end{tabular} \begin{tabular}{|l|l|l|l|l|l|l|l|l|l|l|l|}
$20-22$ & $20-23$ & $20-24$ & $20-25$ & $20-26$ & 0.0391 & 0.0390 & 0.0393 & 0.0388 & 0.0391 & 0.0392 & 0.2345 \\
\hline
\end{tabular}

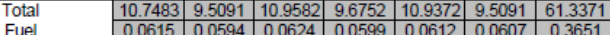


Target ID:

Irradiation Conditions

Irradiation Location (R, A)

Number cycles

First Cycle Goal

Fill Gas

Irradiation Temperature

Assembly drawing

Welding drawing

Capsule Fabrication

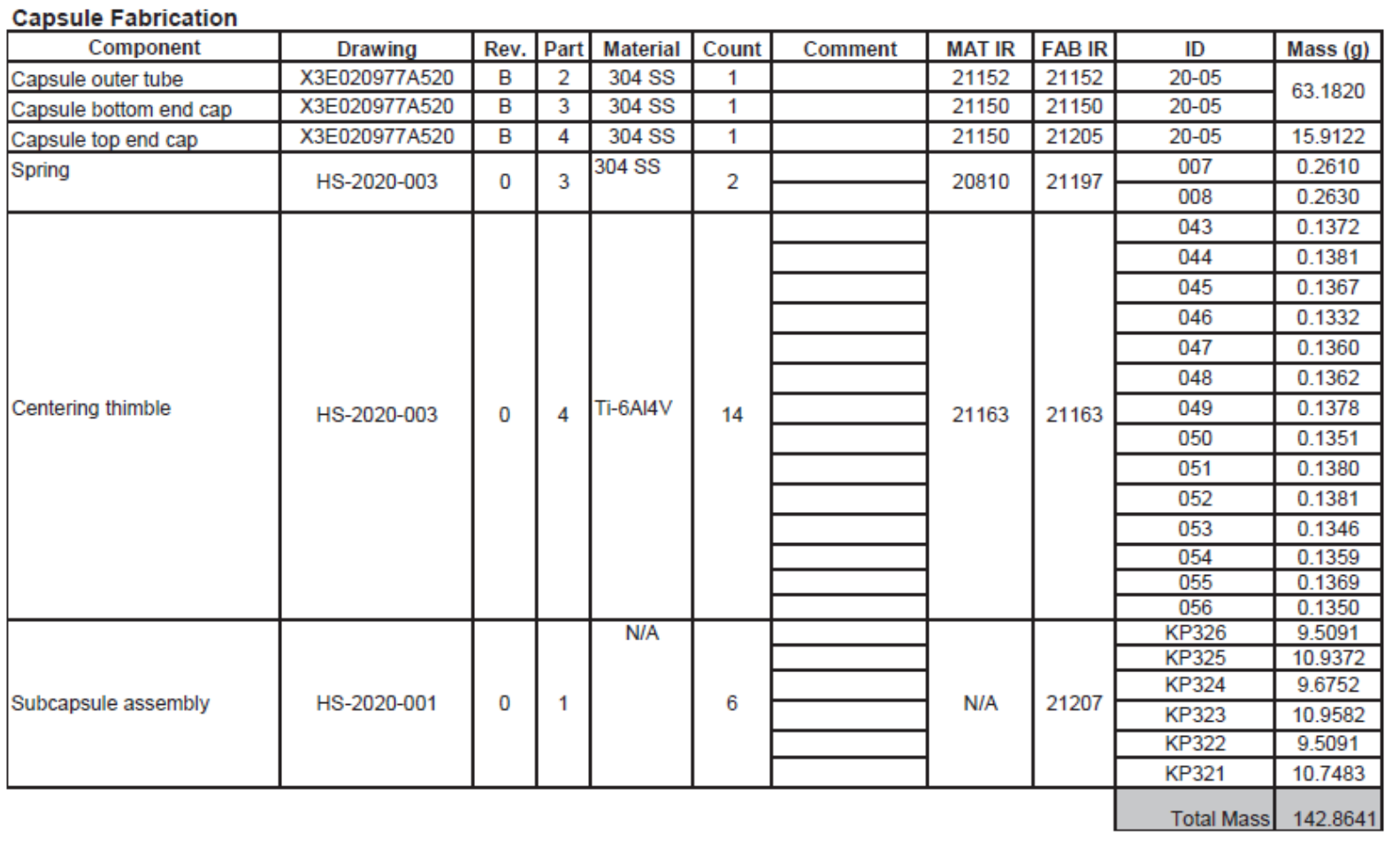

Holder Sub-Assemblies

\begin{tabular}{|c|c|c|c|c|}
\hline Holder ID & $\begin{array}{c}\text { S = Sub-Assembly } \\
\text { Position }\end{array}$ & $\begin{array}{c}\text { R-A-S } \\
(\mathbf{R}=\text { Radial target position, A = Axial target position) }\end{array}$ & $\begin{array}{c}\text { Holder } \\
\text { diameter (mm) }\end{array}$ & Initial \\
\hline KP326 & 6 & $3-2-6$ & 8.58 & DB \\
\hline KP325 & 5 \\
\hline KP324 & 4 & $3-2-5$ & 9.17 & DB \\
\hline KP323 & 3 \\
\hline KP322 & 2 \\
\hline KP321 & 1 & $3-2-4$ & 8.64 & DB \\
\hline
\end{tabular}

Approvals

\begin{tabular}{|c|c|c|c|}
\hline & Request & Build & \\
\hline Performed by: & 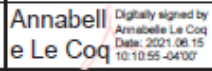 & David Bryant & 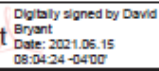 \\
\hline & 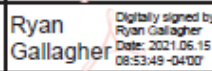 & $\begin{array}{l}\text { Annabelle } \\
\text { Le Coq }\end{array}$ & \\
\hline
\end{tabular}

uivalent

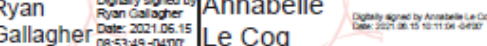

HS-2020-003 Rev. 0

HS-2020-003 Rev. 0

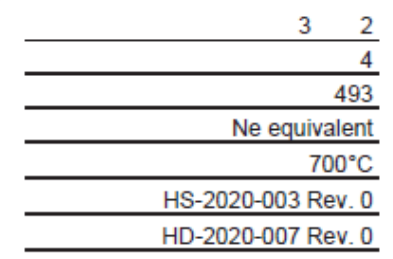

\section{2}

Checked by: 
Target ID:

Irradiation Conditions

Irradiation Location $(R, A)$

Number cycles

First Cycle Goal

Fill Gas

Irradiation Temperature

Holder assembly drawing

Holder assembly welding drawing
Approvals

\begin{tabular}{|c|c|c|c|c|}
\hline \multirow{3}{*}{ Performed by: } & \multirow{2}{*}{\multicolumn{2}{|c|}{ Request }} & \multirow{2}{*}{\multicolumn{2}{|c|}{ Build }} \\
\hline & & & & \\
\hline & Annabelle Le Coq & $\begin{array}{l}\text { Digitally signed by Annabelle Le } \\
\text { Cog } \\
\text { Date: } 2021.05 .2700: 06: 04-04^{\prime} 00^{\prime}\end{array}$ & $\begin{array}{l}\text { Christopher } \\
\text { Hobbs }\end{array}$ & 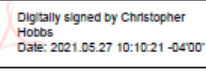 \\
\hline Checked by: & Ryan C. Gallagher & $\begin{array}{l}\text { Digitally signed by Ryan } \mathrm{C} \text {. } \\
\text { G Gallagher } \\
\text { Date: } 2021.05 .27 \quad 10: 44: 28-0400^{\prime}\end{array}$ & \multicolumn{2}{|c|}{ David Bryant } \\
\hline
\end{tabular}

Holder Assembly

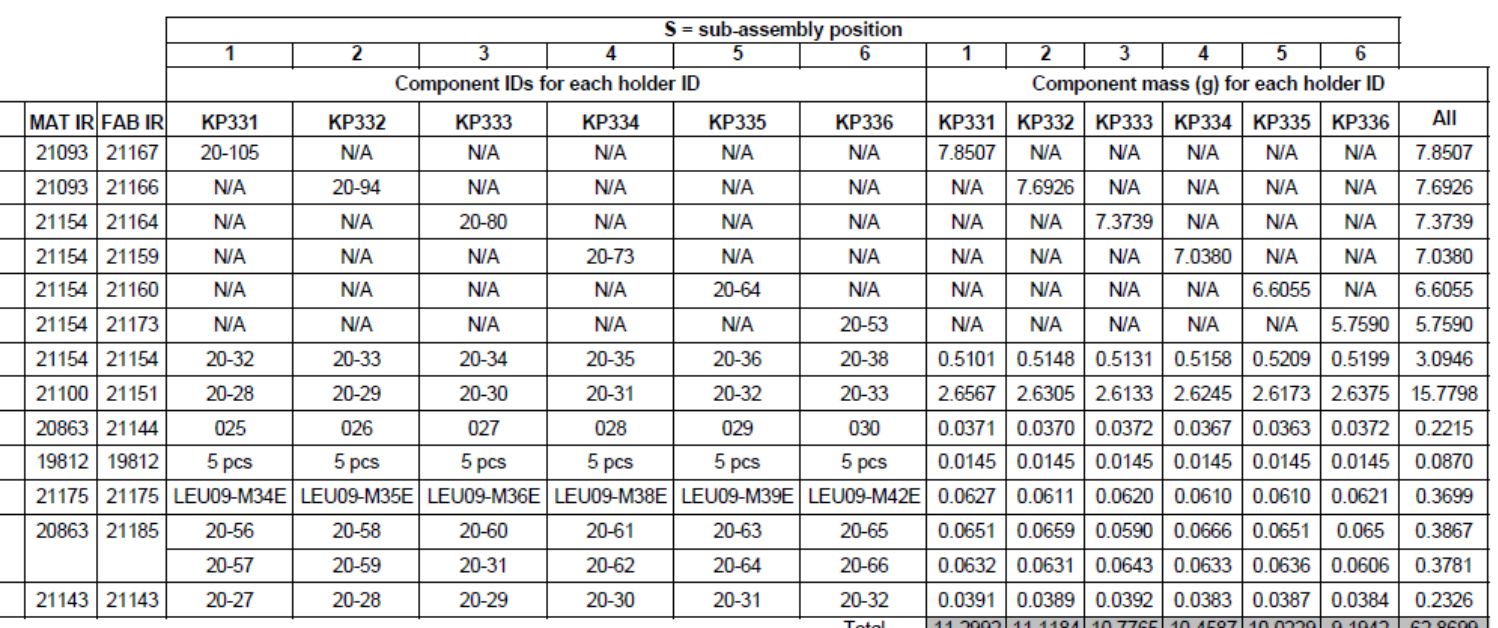

Graphite

\begin{tabular}{l|c|c|c|c|c|c|c|}
\hline Total & 11.2992 & 11.1184 & 10.7765 & 10.4587 & 10.0229 & 9.1942 & 62.8699 \\
\cline { 2 - 8 } Fuel & 0.0627 & 0.0611 & 0.0620 & 0.0610 & 0.0610 & 0.0621 & 0.3699 \\
\hline
\end{tabular} 


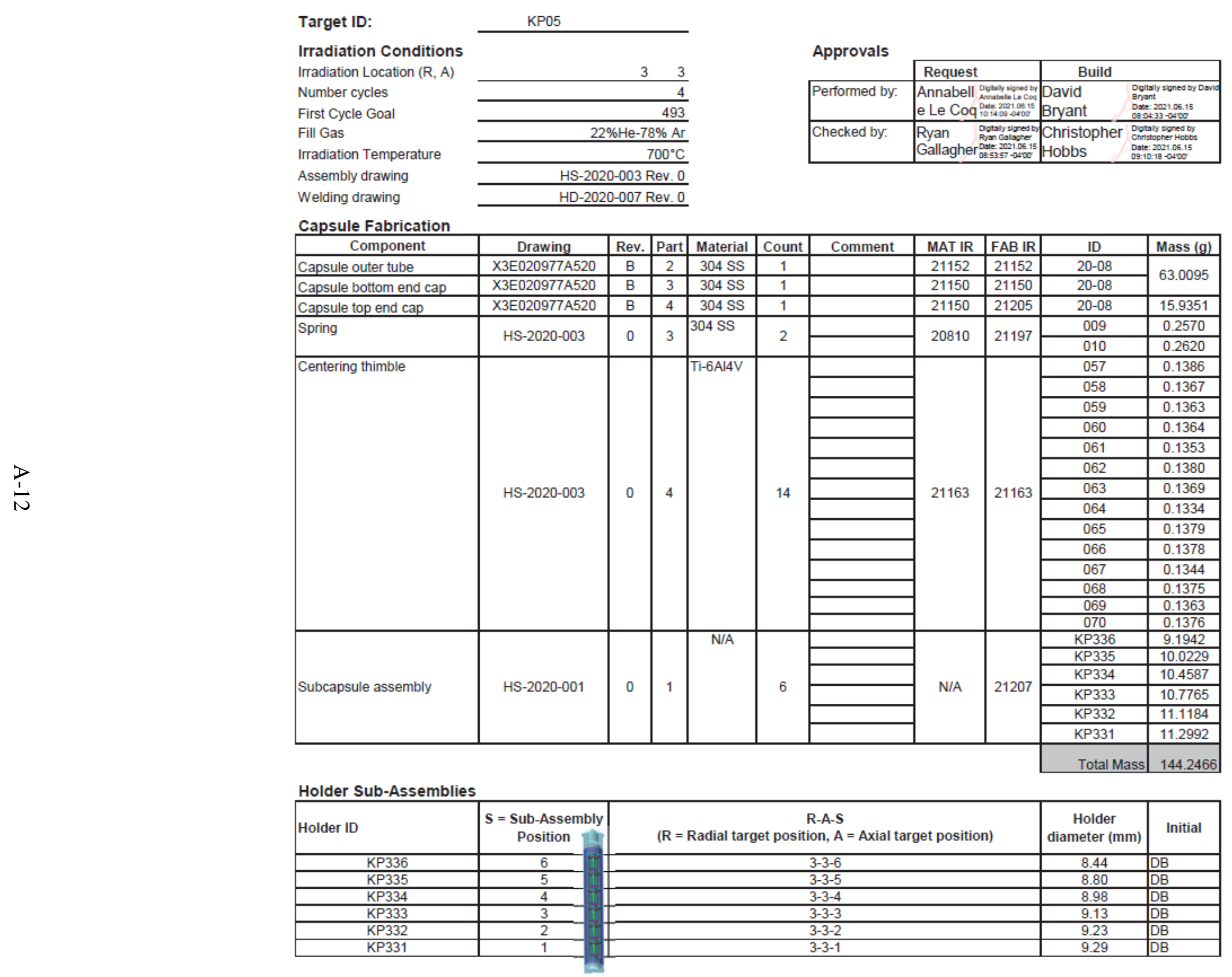





\section{APPENDIX B. EXPERIMENT AUTHORIZATION BASES DOCUMENT}

\begin{tabular}{|c|c|}
\hline $\begin{array}{l}\text { Experiment Authorization Bases Document: EABD-HFIR-2018-001 } \\
\text { Title: "Irradiation of Miniature Fuel Specimens in the Inner Small VXF Positions" }\end{array}$ & $\begin{array}{c}\text { Rev } 1 \\
\text { Page } 8 \text { of } 12\end{array}$ \\
\hline
\end{tabular}

\begin{tabular}{l} 
Section 6: Acceptance for Use of \\
Note: This section is used to document acce \\
irradiation. This section is completed after \\
\hline \multicolumn{1}{|c|}{ 1. List Applicable Component Identificati } \\
Basket ID: MFB \\
Flux monitor IDs for Basket: 1,2 \& 3 \\
\begin{tabular}{|l|c|}
\hline Target I.D. (as marked) & Dummy target \\
\hline KP02 & $\square$ \\
\hline KP03 & $\square$ \\
\hline KP04 & $\square$ \\
\hline KP05 & $\square$ \\
\hline & $\square$ \\
\hline & $\square$ \\
\hline & $\square$ \\
\hline & $\square$ \\
\hline
\end{tabular}
\end{tabular}

2. Approvals (see notes for explanation of signature responsibilities)

Ryan C. Gallagher

zyan C Gallagher

Lead Experimenter

Lead Experimenter (signature)

$06 / 16 / 2021$

MCVance

Lead QA

SAVID S. KOZLOWSKY

RRD NQR

Greg Hit $\mathrm{f}_{\mathrm{z}}$

E\&FI Staff

* B. L. Lee

RRD Criticality Safety Officer

Darid Stanlay

HFIR MBA Representative

David Stanley

HFIR Operations (print name)

Me vanes

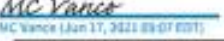

Lead QA (signature)

Aarelof pounto

RRD QA (signature)

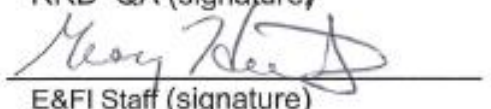

E\&FIStaff (signature)

B. La Lee

RRD Criticality Safety Officer (signature)

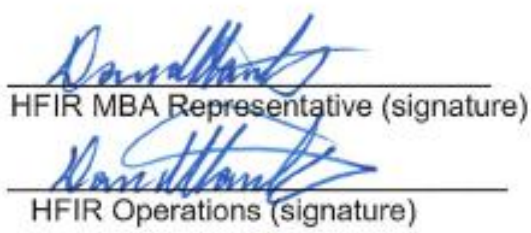

Date

$\frac{06 / 17 / 2021}{\text { Date }}$

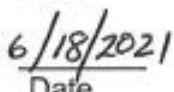

$\frac{\mathrm{C} / 21 / 2021}{\text { Date }}$

$06 / 02 / 2021$

Date

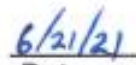

Date

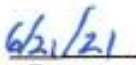

* RRD Criticality Safety Office item is pre-signed on the basis that the design content will not deviate and conforms to the specifications contained in this EABD. If Att B identifies a NCR or Deviation then the CSO shall be included as party to the specific document or shall acknowledge the change by initial and date in the above signature block. 
